\title{
Evaluating the Long-term Effectiveness of English Language Coursebooks at Turkish Public High Schools
}

\author{
Mehdi Solhi a * (D), Yaren Zehra Mert a (D), Zeliha Çelen ${ }^{\mathrm{b}}$ (D), \\ Rabia Kısa a \\ a The Department of English Language Teaching, School of Education, Istanbul Medipol University, Turkey \\ ${ }^{b}$ Ataşehir Bilfen Preschool, Istanbul, Turkey
}

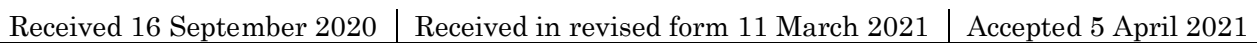

APA Citation: Solhi, M., Mert, Y. Z., Çelen, Z., \& Kısa, R. (2021). Evaluating the long-term effectiveness of English language coursebooks at Turkish public high schools. Eurasian Journal of Applied Linguistics, 7(1), 458-483. Doi: 10.32601/ejal.911493

\begin{abstract}
In this pre-use evaluation study, the long-term effectiveness of the contents of the English language coursebooks provided by the Ministry of Turkish National Education for high school students (i.e., 9th to 12th graders) in Turkey were evaluated, exploiting Tomlinson and Masuhara's (2013) fifteen universal coursebook evaluation criteria. In so doing, the evaluators initially used the criteria independently to evaluate the coursebooks before achieving a consensus on their average scores. They discussed each criterion along with the effectiveness of the activities in two units (i.e., Unit 2 \& Unit 7). The results indicated that the coursebooks are potentially quite effective in respect of providing students with communicative opportunities, use of idioms, integrated technology, self-evaluation opportunities, and illustrations in use. Conversely, some of the common deficient characteristics of the coursebooks encompass the lack of activities that promote the use of English as a lingua franca, being void of opportunities for students to continue learning English after the course, offering no flexibility for effective localization and insufficient catering for the needs of the students. All in all, the coursebooks can only be partially effective in facilitating long-term acquisition of English.
\end{abstract}

(C) 2021 EJAL \& the Authors. Published by Eurasian Journal of Applied Linguistics (EJAL). This is an open-access article distributed under the terms and conditions of the Creative Commons Attribution license (CC BY-NC-ND) (http://creativecommons.org/licenses/by-nc-nd/4.0/).

Keywords: Coursebooks evaluation; coursebook deficiency; public schools; English deficit

\section{Introduction}

All the instruments that facilitate and encourage language learning can be referred to as language learning materials. Gray (2006) characterizes materials as anything that is exploited in helping language acquisition, including coursebooks, practice books, audiotapes, CDs, and gifts. In sum, they allude to anything that contributes to

\footnotetext{
* Corresponding author. Tel.: +90 2166815100 (1717)

E-mail address: solhi.mehdi@gmail.com

http://dx.doi.org/10.32601/ejal.911493
} 
the learners and presents them the knowledge about the language they intend to acquire. Indeed, the current materials that are being used in language classrooms offer students inclusive learning packages and they have undeniably improved the effectiveness of classroom activities over recent years (Littlejohn, 1998). A dynamic language lesson can be achieved if the learners and the teacher are interactively involved in using the materials (Allwright, 1981). Crewe (2011) similarly exhibits the premise that learning and teaching process is composed of three fundamental assets: learners, teachers, and materials for instructions.

Being the most widely recognized and used instructional materials and tools, coursebooks play an immense role in language teaching and learning (Sercu, 2005). Generally, coursebooks provide a structured content that is ready for use. Indeed, they are an essential source and key to an active teaching and learning process, not only for school but also for higher education institutes. As Haycroft (1978) expressed almost four decades ago, not only can the coursebooks offer the teacher the authority he or she needs for effective language teaching, but they can also provide students a rich wealth of information for learning. Additional positive traits of coursebooks involve granting a face validity to language learning (Dubin \& Olshtain, 1986), delivering a learning scaffolding (Kramsch, 1988), supplying details on the procedures in the classrooms (Hutchinson \& Torres, 1994), playing the role of a resource and point of a reference (Cunningsworth, 1995), helping the students to develop their intercultural competences (McKay, 2003), helping to establish the principles of language courses (Davcheva \& Sercu, 2005), exhibiting an important role in structuring a language lesson (Gray, 2006), presenting important values and culture (Bahman \& Rahimi, 2010), functioning both as a general framework and a syllabus for language process (Tsiplakides, 2011), supplying similar content for different classrooms and lessons as well as facilitating the process of evaluation (Abdelwahab, 2013), and reducing the time spent on preparations (Tsiplakides, 2011; Dodgson, 2019). However, despite the abovementioned characteristics of the coursebooks and materials in language education, it was only in the 1990s when educators and researchers began paying in-depth attention to materials and their evaluation, and since then materials have been taken into thorough account in language education.

Tomlinson (2013a, p. 1) defines material evaluation as "procedure of defining the value (or potential value) of classroom materials". He adds that the evaluation process includes the measurement of the influence they implement on the learners. Indeed, material evaluation attempts to measure to what extent the materials are motivating, reliable, valid, credible, interesting, appealing, and adaptable, and how much they may lead to short and long-term learning of a language. Additionally, learners and the teachers' beliefs on the long-term effectiveness of the materials, and the extent to which they can contribute to teacher development are taken into consideration in material development. It is worth noting that in material evaluation the effect of the materials on the learners, rather than the materials themselves, is taken into account. Therefore, materials evaluation deals with the individuals who use them and intends to indicate how effective they are on the users. Almost thirty years ago, 
Sheldon (1988) stated that materials evaluation is principally subjective since there is no standard framework for coursebook evaluation. Tomlinson (2013a) similarly advocates that no matter how much an evaluation claims to be criterion referenced, standardized, and accurate, the materials evaluation is subjective by its nature. To sum up, no evaluations of the effectiveness of the materials are ever likely to come up with the same results as the individuals' styles, backgrounds, and expectations tend to be different in the contexts the materials are used.

In contrast, materials analysis differs from evaluation by inspecting the materials themselves rather than scrutinize the possible effects they might have on the individuals who use them. Indeed, the approach in materials analysis tends to be objective, while that in evaluation is subjective. Therefore, in materials analysis, the focus is on the content, instructions, tasks, and the goal in the materials (Tomlinson, 1999). For example, an analyst may ask "Does the coursebook provide the transcript of the listening activities?" to see if the tapescripts are provided in the coursebook, while an evaluator may ask "To what extent do the listening activities in the coursebook target the learner involvement?" According to Tomlinson (1999), even though a material analysis tends be objective, analysts are generally persuaded by their own perceptions while preparing the questions, which may result in the questions that tend to be biased. To give an example, an analyst might ask the question "Does the coursebook provide a lot of guided speaking activities?" In this example, the analyst's use of a quantifier 'a lot' in the question exhibits his/her hidden agenda and is likely to lead to a biased analysis of the content of the material.

Tomlinson (2013a) classifies materials evaluation into three types: pre-use, whilstuse, and post-use evaluation. In pre-use evaluation, evaluators come up with the premise and predict the potential effectiveness of the contents of the materials for the potential users. In this manner, an evaluation must be criterion referenced, standardized, and accurate with the participation of at least two evaluators to maximize the reliability of the evaluation. Initially, the evaluators need to conduct the process of evaluation independently and then try to reach a mutual compromise on their evaluation. Whilst-use evaluation contains exhibiting the effectiveness of materials in actual teaching practices. In contrast to pre-use evaluation, this kind of evaluation is more reliable and objective as it assesses the real usage of the contents of the materials in lieu of forming hunches on their effectiveness. Yet, the premise of the long-term value estimation and effectiveness of the materials seem to be quite farfetched since it can only estimate and measure the noticeable performances of the users in a particular teaching setting. Post-use evaluation, as the most valuable type of evaluation, possesses a higher potential to exhibit the genuine value and the results of the materials on the individuals who would use them. In post-use evaluation, both the short-term values of the contents (e.g., instant learning, motivation, and achievability) and their long-term effectiveness (e.g., durable learning and implementation) can be explored. Indeed, we can reach more reliable outcomes on how to use, replace, and adapt the contents of the materials after conducting the post- 
use evaluation. However, carrying out this posterior evaluation demands a considerable amount of time and knowledge in the field (Tomlinson, 2013a).

In fact, considering the importance of language learning materials and particularly coursebooks, coursebook evaluation can be quite insightful in terms of identifying their long-term effectiveness in language education across the world. Undoubtedly, the commerce of the English language coursebooks publishing is an extremely competitive and growing industry across the world (Gray, 2002), and it is estimated that only British English language coursebooks' annual sales amount to 70 to 170 million pounds (Pennycook, 1994). Indeed, the demand for English language materials has made English language publishers to be one of the fastest growing industries worldwide, and thereby the countries such as Turkey with the highest, and of course the youngest, population in Europe have been considerably tempting to the publishers.

Being taught as a foreign language in Turkey, English is deemed as a mandatory and needful language in the education system. The quick expansion of English as an international language in recent decades has significantly impacted the non-native speaker nations' measures and reforms in respect with the role of the second or foreign language in the countries. As a result of globalization and thereby the accelerating necessity for an international language, and with the purpose of adapting the foreign language education in the country to European Union guidelines, the Turkish government has commenced directing more assiduous attention to English language in recent decades. Following the educational reforms in 1997, the English language instruction, once taught in the secondary school, shifted to the primary school. After that, in 2011, the Ministry of National Education introduced a set of practical measures aimed at improving the foreign language instruction in the country with the purpose of recruiting 40 thousand foreign English teachers at state schools. As an outcome, in 2012, the instruction of English became mandatory from the second grade to the end of the twelfth grade, and teaching hours increased.

However, notwithstanding the reform movements and the early commencing of English instruction in the second grade, the Turkish students have not seemingly been able to achieve the anticipated proficiency in English language. As reported by a globally recognized renowned English proficiency index (i.e., the EF EPI), Turkey has steadily ranked noticeably low in English proficiency. For instance, in the EPI 2013 report Turkey ranked $41^{\text {st }}$ among sixty nations (Vale et al., 2013). Turkey's unsatisfactory English proficiency went downhill in 2014, and the EPI report placed Turkey $47^{\text {th }}$ in the world and at the bottom of the list between the 24 European countries. This steady decline accelerated as Turkey's English proficiency ranking in the global proficiency benchmark was 77th among 88 countries in 2018 and 79 th out of 100 countries in 2019. Nor has Turkey's performance on globally recognized tests such as Test of English as a Foreign Language (TOEFL) been auspicious. In 2012, for instance, the country's average score in TOEFL was 75, which made its ranking at the bottom of the list in the vicinity of Ethiopia and Sudan. In fact, all these figures 
highlight the unpalatable home truth about deficiency in English education in Turkey.

Indeed, as stated, Turkey has been underachieving in foreign language education, and English inadequacy of Turkish learners has been a heated topic of discussion down the years. Notwithstanding the measures taken by the ministry of education to ameliorate the current defective situation in language education, the attempts and the reforms, as aforementioned, have gone off at half-cock! With the premise that the English as a foreign language coursebooks possess a prominent role in language education, the evaluation of the coursebooks that are exploited in Turkish public high schools through the universal coursebook evaluation criteria would enlighten the educators and English language teachers about the effectiveness of their contents and to what extent they can realistically result in the long-term acquisition of English in Turkish public schools. In this endeavor, we explored the long-term effectiveness of the abovementioned coursebooks that are utilized in English courses of Turkish public high schools to identify the potential reasons behind the English deficiency of Turkish high school students.

\subsection{Literature review}

Tomlinson (2003a, p. 23) argues that many studies on materials and coursebook evaluation do not differentiate between analysis and evaluation, and they mix both procedures. Hence, this is less likely to employ the criteria effectively as most of the analysis questions would "be weighted disproportionately when combined with evaluation questions". Tomlinson (2012) reports a varying number of coursebook evaluation checklists in the literature of evaluation criteria, indicating that many are inadequate in terms of generalizability, validity, answerability, clarity, and specificity. He believes that some are void of a principled base, systematicity, and/or coverage and some convey the impression that they could be used in any materials evaluation.

In pre-use evaluation, the use and development of a standardized and accurate criteria checklist for materials evaluation has been consistently prevalent over the last decades so as to ease the selection of appropriate materials (e.g., Skierso, 1991; McDonough \& Shaw, 1993; Cunningsworth, 1995; Ur, 1996; Brown, 1997; Chambers, 1997; Littlejohn, 1998; Gearing, 1999; Byrd, 2001). Despite the varying number of pre-use evaluation checklists, none is practically one-size-fits-all (Tomlinson, 2013a), and the large number of the checklists are bound to particular contexts (Mukundan \& Ahour, 2010).

Indeed, owing to the fact that the majority of the coursebook evaluation checklists do not offer any rating and weighting schemes (Şimşek \& Dündar, 2018), a group of scholars (e.g., Mukundan \& Ahour, 2010) advocates the premise of using a more flexible set of criteria instead of using or developing an unyielding checklist which tends to be context-specific, Hence, this type of criteria is more likely to "apply to any language learning materials anywhere for any learners" (Tomlinson, 2013b, p. 37). 
Indeed, Tomlinson (2003b) lists ten necessary steps that need to be taken to develop such kind of criteria for coursebook evaluation.

In the process of developing the coursebook evaluation criteria, at the outset, Tomlinson, Dat, Masuhara, and Rubdy (2001) used a list of 130 criteria for coursebook evaluation; however, Masuhara, Hann, Yi, and Tomlinson (2008) reduced the items in the list to 104 criteria. Indeed, they believed that the revised checklist would properly reflect the principles of language acquisition and learning in the materials. In 2013, Tomlinson and Masuhara reduced the items to 15, assuming that the revised checklist would "best predict the long-term effectiveness" of the coursebooks. They add that the 15-item universal criteria are rigorous and systematic, emerging from their experiences as "learners, teachers, materials developers, and researchers and from... [their] understanding of the findings of current research and theory in classroom research" (p. 234). Tomlinson (2013a) recommends the evaluators developing their own set of universal criteria for evaluating materials. He outlines a universal set of criteria as a measure which can be implemented "to any language learning materials anywhere for any learners" (p. 37). Tomlinson and Masuhara's (2013) set of universal criteria claims to accurately estimate the long-term value of the contents of the coursebooks. The criteria are as follows:

To what extent is the coursebook likely to

1. provide extensive exposure to English in use?

2. engage the learners affectively?

3. engage the learners cognitively?

4. provide an achievable challenge?

5. help learners to personalize their learning?

6. help the learners to make discoveries about how English is typically used?

7. provide opportunities to use the target language for communication?

8. help the learners to develop cultural awareness?

9. help the learners to make use of the English environment outside the classroom?

10. cater for the needs of all the learners?

11. provide the flexibility needed for effective localization?

12. help the learners to continue to learn English after the course?

13. help learners to use English as a lingua franca (ELF)?

14. help learners to become effective communicators in English?

15. achieve its stated objectives?

A range of studies have investigated the perceptions of students and instructors regarding the efficacy of textbooks employed in Turkish schools. For example, Özdemir (2007) examined students and teachers' perceptions towards the efficacy of 
Time for English coursebook that is employed in the fourth-grade Turkish public school. The findings indicated a significant contentedness about the coursebook with a greater satisfaction rate among students. While the songs and instructions in the book were identified as troublesome parts by the students, the teachers pinpointed the vocabulary sections, unit numbers, the presentation of language elements and the teacher's books as other shortcomings of the coursebook. Similarly, Arıkan (2008) explored both fourth graders and the instructors' beliefs regarding the effectiveness of the textbooks. The findings revealed that while only around 30 percent of the participating teachers exhibited their positive attitude towards the textbooks, approximately 60 percent of the participating students showed a positive attitude towards the overall content of the textbooks. Additionally, half of the participating students $(\mathrm{N}=352)$ stated that the organization of the textbook and the design were satisfying, while only about 33 percent of the participating instructors stated that they were satisfied with these features. In fact, in both studies, higher student satisfaction than that of teachers has been reported, and both students and teachers identified quite different and distinct elements as deficiencies of the materials. It is noteworthy that the studies were conducted with a group of elementary school students and teachers, and the materials that are used at this grade. The higher contentedness on the part of the elementary school students can be attributed to colorful illustrations in use and affective engagement of the materials (Solhi, Sak Masrı, Şahin, \& Yılmaz, 2020). Since the elementary school students are mainly young learners aging 8 to 10 years old, the integration of attention getting illustrations and drawings can be attention grabbing and is more likely to trigger engagement. In fact, Solhi et al.'s (2020) study exhibited that there are a varying number of entertaining activities and puzzles in the elementary school coursebooks that can make the tasks more affectively engaging.

In a recent investigation, Dülger (2016) investigated 118 Turkish teachers' perceptions on the effectiveness of public-school English language textbooks. The participants gave the greatest average score to the curriculum and syllabus, while the areas such as writing, grammar, speaking, and listening scored below the average. Additionally, vocabulary and reading achieved a mediocre score amid the other skills. Similar to Dülger's (2016) investigation, Çakıt (2006) and Kayapınar's (2009) studies identified that the students and the teachers similarly do not have positive viewpoint about the textbooks, and they advocate improving the contents of the textbooks so as to meet the Turkish students' needs in foreign language education. Recently, Öz (2019) also indicated that both students and teachers were moderately satisfied with the textbooks, while they did not exhibit satisfaction with the practical parts of the textbooks. In short, the studies on the efficacy of the English coursebooks that are utilized in Turkish public schools do not prove to be eminently satisfactory.

\section{Method}

Despite the existing wealth of evaluating studies on English language teaching coursebooks that are utilized in Turkish public schools, the large bulk of the 
evaluation has only focused on the students and the teachers' perceptions of the materials (e.g., Çakıt, 2006; Arıkan, 2008; Kayapınar, 2009; Dülger, 2016; Akkaya, 2019; Öz, 2019), and there are only a few evaluation studies that systematically evaluate the English language textbooks that are employed in Turkish public high schools (e.g., Aytuğ, 2007). However, evidently, there are few arrays of studies which measure and evaluate the efficiency of English language coursebooks applying Tomlinson and Masuhara's (2013) set of universal criteria. In so doing, in this pre-use evaluation study, the four English language learning coursebooks provided by Turkish Ministry of National Education for the 9th, 10th, 11th and 12th grades of Turkish public high schools were taken into scrutiny.

As aforementioned, in pre-use evaluation, evaluators come up with the premise and predict the potential effectiveness of the contents of the materials for the potential users. The participation of at least two evaluators is required so as to maximize the reliability of the evaluation, (Tomlinson \& Masuhara, 2013). In so doing, all of us initially conducted the process of evaluation independently and then we came together to reach a mutual compromise on our evaluation. We used Tomlinson and Masuhara's (2013) fifteen universal coursebook evaluation criteria to make the evaluation criterion-referenced, standardized, and accurate. Due to the fact that the outline of the all the units in the coursebooks is totally similar, and as this is not practically feasible to evaluate all the units of the coursebooks, Tomlinson and Masuhara (2013) implicitly recommend selecting two units that can potentially represent all the contents of the coursebooks. In our pre-use evaluation, after a short but effective discussion about which units to choose, we made a consensus on units 2 and 7 of the four coursebooks, since it was agreed that these two units were able to represent the other units in the coursebooks and the units would be able to give a wider perception of the coursebooks. The research questions are Tomlinson and Masuhara's (2013) fifteen universal coursebook evaluation criteria that are listed in the introduction section of the paper.

It is worth underlining that the selected coursebooks have been approved and funded by the Turkish government, and they are the mostly used coursebooks for public high school students' English education in Turkey. The details about the coursebooks we have evaluated are in Table 1 . These coursebooks were used in 20192020 educational years by public schools' 9 th, 10th, 11th, and 12 th grade students in Turkey. All the coursebooks contain 10 different units. These coursebooks contain $142,160,167$, and 112 pages in total respectively.

Table 1. Public high school coursebooks

\begin{tabular}{lll}
\hline Coursebook & Authors & Publisher \\
\hline Teenwise 9 & $\begin{array}{l}\text { Ebru Bulut } \\
\text { Funda Baydar Ertopçu } \\
\text { Seda Umur Özdali } \\
\text { Sibel Şentürk }\end{array}$ & Meb Publishing \\
& Çiler Genç Karataş & \\
English 10 & & Gizem Publishing
\end{tabular}




$\begin{array}{lll}\text { Sunshine English } & \text { Müge Akgedik Can } & \text { Cem Publishing } \\ & \text { Neslihan Atcan Altan } & \\ \text { Count Me In } & \text { Fethi Çimen } & \text { Meb Publishing } \\ & \text { Bilgen Taşkiran Tiğin } & \\ & \text { Ayten Çokçalişkan } & \\ \text { Nihan Özyildirim } & \\ & \text { Mustafa Özdemir } & \end{array}$

\subsection{Data collection procedure}

In analyzing qualitative data, a method of reporting described as "thick description" (Mackey \& Gass, 2016, p. 231) is used to determine the similarity of context. In this method, several perspectives are exploited to elaborate the insights gathered from a study. In fact, the premise behind thick description is providing adequate details for readers to comprehend the features of research context so as to be able to "compare the research situation with their own and thus determine which findings may be appropriately transferred to their setting". They emphasize that this step can increase the external validity of qualitative research. In addition, in interpreting qualitative data, "triangulation" encompasses exploiting several sources of data and different research techniques to investigate and evaluate the data from multiple perspectives (Mackey \& Gass, 2016, p. 233). Triangulation can also augment the validity and reliability of analyzing qualitative research. Investigator triangulation (i.e., using several evaluators) is a type of triangulation that is used in a single investigation to reach at the similar research findings in qualitative studies. In fact, triangulation can reduce the researcher and evaluator bias in analyzing the qualitative data, and thereby can enhance the reliability and validity of the information (Johnson, 1992).

In this pre-use evaluation study, the techniques of thick description of materials and investigator triangulation were used to increase the reliability and validity of the evaluation. In so doing, four evaluators initially used Tomlinson and Masuhara's (2013) set of fifteen universal coursebook evaluation criteria independently to evaluate the coursebooks before collecting the data and achieving a consensus on their long-term effectiveness. In the pre-use evaluation process, we discussed each criterion along with the long-term effectiveness of the activities in two units (i.e., Unit $2 \&$ Unit 7 ), provided explanations in accordance with the set of 15 universal coursebook evaluation criteria, and finally ranked each criterion with the score of 1 to 3: (1) unlikely to be effective in facilitating long-term acquisition, (2) likely to be partially effective in facilitating long-term acquisition, and (3) likely to be effective in facilitating long-term acquisition. Although the design of the study is qualitative, brief numerical values are reported in this study to simplify the process of interpretations, simple counting, and comparison.

\section{Results}

The results of the study are discussed with the focus on each item in Tomlinson and Masuhara's (2013) set of universal criteria to accurately estimate the long-term value 
of the contents of the coursebooks. Each table (i.e., Table 2 to Table 16) exhibits the thematized evaluations of the 15 criteria listed in the introduction above.

Table 2. Extensive exposure to English in use

\begin{tabular}{|c|c|c|}
\hline Course & Score & Comments \\
\hline Teenwise & 1 & $\begin{array}{l}\text { There are seven too short texts in the units in total; however, none is authentic. } \\
\text { The main exposure to English is listening and speaking activities in the units. } \\
\text { However, similar to the reading texts, listening files are non-authentic, and } \\
\text { thereby students do not seem to be able to have real extensive exposure to English } \\
\text { in use. For example, the activity on page } 111 \text { asks students to listen to people } \\
\text { inviting friends to the parties and match the correct party types. In fact, students } \\
\text { do not seem to hold a real conversation in such kinds of matching activities. }\end{array}$ \\
\hline English 10 & 1 & $\begin{array}{l}\text { Similar to Teenwise, the authentic exposure in the units is too limited. There are } \\
\text { only } 4 \text { reading texts in the units. In fact, there are many short unauthentic } \\
\text { paragraphs and conversations in the coursebook. Even though the videos, audios } \\
\text { and the texts are not authentic, some of them possess contextual English usage. } \\
\text { For example, on page } 25 \text {, there is a video of three people organizing a celebration. } \\
\text { This is an everyday event that highlights everyday use of English language. In } \\
\text { general, the texts mostly target reading comprehension checks, and seem to be too } \\
\text { short for the 10th graders. }\end{array}$ \\
\hline $\begin{array}{c}\text { Sunshine } \\
\text { English }\end{array}$ & 2 & $\begin{array}{l}\text { The texts in the units are neither too short nor too long. The length of texts is } \\
\text { appropriate for the students considering the grade they are in. However, the texts } \\
\text { are not authentic and most of them are used for "fill in the blanks" activities with } \\
\text { the focus on reading comprehension only (e.g., page } 28) \text {. The only exception is the } \\
\text { text from a website on page } 117 \text { which can be considered authentic. }\end{array}$ \\
\hline $\begin{array}{c}\text { Count Me } \\
\text { In }\end{array}$ & 2 & $\begin{array}{l}\text { The length of the texts is average. Similar to the other coursebooks, most of the } \\
\text { readings focus only on the comprehension check without actively involving the } \\
\text { students. Although the texts try to expose the students to real life experiences and } \\
\text { values, they are unauthentic and seem to be particularly written for the } \\
\text { coursebook. Hence, they are not very likely to prepare the students for real life } \\
\text { encounters. }\end{array}$ \\
\hline
\end{tabular}

Table 3. Affective engagement

\begin{tabular}{ccl}
\hline Course & Score & \multicolumn{1}{c}{ Comments } \\
\hline Teenwise & 2 & $\begin{array}{l}\text { At the end of each unit there is a section that aims to amuse and stimulate the } \\
\text { students affectively. However, the instructions are too short, and they are } \\
\text { impetrative statements with not totally clear explanations. Hence, they are not }\end{array}$ \\
& $\begin{array}{l}\text { likely to engage the learners affectively. In fact, the units in general do not seem } \\
\text { to be able to affectively involve the students. For example, Unit } 2 \text { is on } \\
\text { environment, but it seemingly fails to arouse curiosity of the learners and thereby } \\
\text { facilitate affective engagement. }\end{array}$
\end{tabular}

English $10 \quad 1 \quad$ The texts in the units can hardly excite the students. Even though some topics are potentially engaging (e.g., Modern Heroes \& Heroines, Unit 9), the activities fail to fulfill the affective engagement and thereby unlock the potential. In fact, the activities are not exciting despite having the potential to stimulate affective engagement. 


\begin{abstract}
Sunshine $\quad 2 \quad$ The topic of Unit 9 is friendship but except for the first two pages, the unit drifts English away from the topic and focuses on celebrities and their lives. The contents of the unit (e.g., talking about celebrities) seem to be interesting, and are likely to arouse the students' curiosity. A few activity designs are colorful and attention grabbing; however, they seem to be repetitive which dims the possibility of affective engagement. The activities need be replaced by different and more engaging activities or questions to avoid boredom and inflict amusement. For example, in Unit 2, there are 7 activities that solely aim at retrieving answers from the students. In a similar vein, there are 6 repetitive fill-in-the-blank activities in Unit 9 which do not seem to be able to affectively engage the learners.

Count Me 1 The units leave the students no room for the affective engagement with the topic, In and the texts do not seem to possess the potential to spark any emotions in students. The activities are mostly comprehension check questions, and do not involve any affective engagement, amusement, or excitement. The topics (e.g., technology in Unit 9) are interesting in theory but the texts themselves are neither engaging nor attention-grabbing. In fact, the texts are mundane, and thereby they provide nothing new, information-wise, and exciting.
\end{abstract}

Table 4. Cognitive engagement

\begin{tabular}{|c|c|c|}
\hline Course & Score & Comments \\
\hline Teenwise & 3 & $\begin{array}{l}\text { Most of the reading texts (i.e., } 5 \text { out of } 7 \text { ) in the units and the activities promote } \\
\text { cognitive thinking and engagement. The activities also promote process-based } \\
\text { answers. For example, on page } 30 \text {, in Unit } 2 \text {, Activity } 7 \text { asks the students to read } \\
\text { the given e-mail example which consists of } 3 \text { paragraphs and put them in a correct } \\
\text { order while reading. Unit } 9 \text { also possesses activities that help students think } \\
\text { analytically and creatively. For example, on page } 118 \text {, one activity asks students } \\
\text { to imagine they are going shopping for a celebration. The students need to think } \\
\text { analytically what they would need to buy in the store. Activity } 3 \text {, on the same } \\
\text { page, also promotes cognitive thinking. It asks students if they know anything } \\
\text { about a festival in India. They are asked to guess what it could be about from the } \\
\text { pictures given. Prediction can help students think cognitively. }\end{array}$ \\
\hline
\end{tabular}

English $10 \quad 1 \quad$ There is no need for students to cognitively engage to complete the activities in Unit 2 because nearly all the questions are comprehension checks. The learners can easily decipher the answers out of the contents or listening audios without analytically and intellectually being involved in them. Similarly, there is only one cognitively engaging activity in Unit 9; the blog entry activity on page 122 allows students to use their cognition as the activity asks them to imagine themselves as a reporter and record a video of them while reporting an interesting event about a new superhero.

Sunshine $\quad 2 \quad$ The activities and questions that come after reading texts and listening audios are English all comprehension check activities which do not require students to use their cognition actively when they answer. They can easily find the answers by reading the texts or listening to the audios. However, there are also a few different cognitively engaging activities in the units. For example, on page 27, students are asked to prepare a poster about their hobbies, likes and dislikes. Another cognitively engaging example is on page 119 , Activity 16 which seems to be able to activate the students' cognitive thinking by asking them to prepare their own classroom magazine by working in groups and collecting some information from their friends and teachers.

Count $M e \quad 1 \quad$ Almost none of the texts or activities in the units encourage the students to think In imaginatively, creatively, and cognitively. The answers to the questions can be found in the texts so the students do not need to use their cognition or critical thinking to answer the questions or do the activities. In fact, neither the activities 
nor the texts let the students come to their own conclusion as the students are constrained by comprehension check questions or matching activities. For example, the first text in Unit 2 asks the students to find out what makes a true friendship, and the answers can be easily found in the text!

Table 5. Achievable challenge

\begin{tabular}{|c|c|c|}
\hline Course & Score & Comments \\
\hline Teenwise & 2 & $\begin{array}{l}\text { The activities in the units can be considered quite achievable for the } 9 \text { th graders } \\
\text { although some are not so easy. There are also some activities that are cognitively } \\
\text { and linguistically challenging to the students. For example, Activity } 3 \text { on page } 29 \\
\text { asks students to write a text about someone's room and complete the sketch for it. } \\
\text { By finding what is missing in the sketch in the texts, the students seem to be } \\
\text { appropriately challenged both linguistically and cognitively. }\end{array}$ \\
\hline English 10 & 3 & $\begin{array}{l}\text { Easy activities abound in Unit } 2 \text {, and they seem to be able to provide achievable } \\
\text { challenges for the students. For example, there is a role-playing activity on page } \\
27 \text { which, at first sight, seems to be somehow challenging for student levels but it } \\
\text { provides the students with the expressions that can make the task challenging. } \\
\text { Similarly, there are linguistically and cognitively challenging activities for the } \\
\text { level of the students in Unit } 9 \text {. For example, Activity A on page } 118 \text { gives the } \\
\text { students four dictionary entries and asks them to write example sentences. The } \\
\text { activity provides two example sentences which make the task more achievable. }\end{array}$ \\
\hline $\begin{array}{c}\text { Sunshine } \\
\text { English }\end{array}$ & 2 & $\begin{array}{l}\text { Several activities provide an achievable challenge to the students. However, some } \\
\text { activities seem to be quite cognitively and linguistically challenging to the } \\
\text { students. For example, on page } 24 \text {, one activity gives some information about } \\
\text { celebrities' hobbies and interests in a couple of words, and then asks the students } \\
\text { to form sentences and write about each celebrity's hobbies and interests. A similar } \\
\text { activity on page } 114 \text { gives the students a quote, asks them what it means, and if } \\
\text { they agree or disagree with it. However, there is no explanation about the } \\
\text { quotation. Achieving the goals of these activities without possessing linguistic } \\
\text { competence and required vocabulary knowledge seems to be a bit challenging. }\end{array}$ \\
\hline $\begin{array}{c}\text { Count Me } \\
\text { In }\end{array}$ & 1 & $\begin{array}{l}\text { Half of the unit activities (e.g., Activity C on page } 25 \text { and Activity B on page } 91 \text { ) } \\
\text { are too easy as the answers are provided within the texts. These activities are not } \\
\text { very challenging for the students but the other half (e.g., Activity C on page } 94 \& \text { } \\
\text { Activity A on page } 86 \text { ) seems to be more challenging. For example, one activity } \\
\text { asks the students to write opinion essays (e.g., for/against essays). However, some } \\
\text { examples and clues are provided to facilitate the tasks. Overall, the activities are } \\
\text { too easy to do or too challenging to perform for the } 12 \text { th grade students. }\end{array}$ \\
\hline
\end{tabular}

Table 6. Personalizing learning

\begin{tabular}{lcl}
\hline Course & Score & \multicolumn{1}{c}{ Comments } \\
\hline Teenwise & 3 & $\begin{array}{l}\text { Each unit has questions at the outset which seeks to elicit students' opinions on } \\
\text { the themes. There are also a lot of activities that ask the students to talk about } \\
\text { their own life and experiences. For example, Activity } 5 \text { and Activity } 7 \text {, on page 27, } \\
\text { respectively ask the students to check the statements that match to their own } \\
\text { lives, bring photos of their own room, and compare them with other students' } \\
\text { photographs. }\end{array}$
\end{tabular}


English $10 \quad 1$ In contrast to Teenwise, the activities in this coursebook give fewer opportunities to the students to personalize their learning. They are only based on the people in the texts, listening audios or videos. The questions do not seem to involve students' personal lives at all. For example, in one of the activities there is a statement 'If I were a superhero, I'd be wonder woman.' Such kinds of activities would not involve the learners to decide what they would like to be based on their personalities. Hence, they seem to fail to help personalize their learning as the activity already decides for them.

Sunshine English

Count Me In
The units begin with personal questions about the students' own lives. For example, Unit 2 starts with 'What kind of activities do you like/dislike doing?' and Unit 9 with 'Who is your best friend?' There are also some activities on pages 117 and 123 in Unit 9 about Turkey and Turkey's history. Such kinds of activities can potentially function as cultural connecting for the students. Therefore, they seem to be able to help learners to personalize their learning.

Most of the activities in the units do not require personalized answers. The students are expected to complete the activities by either reading the texts or using the points and clues given in the texts about the people they do not personally know. Only 6 out of 49 activities in two units have activities that allow students to answer by using their personal points, ideas, opinions, and favorites. The rest is all comprehension check questions, and do not seem to help learners to personalize their learning.

Table 7. Making discoveries about how English is typically used

\begin{tabular}{|c|c|c|}
\hline Course & Score & Comments \\
\hline Teenwise & 1 & $\begin{array}{l}\text { Most of the activities in the units are practice, comprehension check, and } \\
\text { matching activities; however, there are some asking learners to guess from } \\
\text { evidence but what the students guess is not about the language itself. For } \\
\text { example, Activity } 3 \text { on page } 118 \text { asks the students to look at the photos of a } \\
\text { festival in India and to explain what they know about the festival while coming up } \\
\text { with some ideas. In fact, the activity could have been assigned to the students to } \\
\text { make them do some investigation at home before they have some conversations } \\
\text { with their partners. There is an 'idiom of the week' activity in each unit, which } \\
\text { shows the students how English phrases and idioms are typically used in real life } \\
\text { but offers them no opportunities to make discoveries or think about the idioms } \\
\text { and possibly their equivalences in their own language. }\end{array}$ \\
\hline
\end{tabular}

English $10 \quad 2 \quad$ There are some consciousness-raising activities (e.g., the idioms/proverbs corners) in the units, which require the students to discover English language points. For example, in Unit 2 on page 25, the idioms are in italics and the students are required to read some short excerpts from a video they would watch. They are supposed to pay attention to the idioms in bold and write their meanings after watching the video. The activity can potentially help students guess and discover the meanings of the idioms from contexts. In another similar idiom activity on page 121, the students are asked to read the sentence that contains a proverb from an audio they would listen to. The activity then asks them why the hero uses the idioms. Such kinds of meaning guessing activities seem to be able to help the students make discoveries about how English is typically used.

Sunshine $\quad 2$ The activities mostly ask students if they comprehend what they read, listen, or English watch. However, in each unit, there are at least two idiom/proverb activities of the week which indicate students how English phrases and idioms are typically used in real life by giving them a proverb and asking them to choose the correct meaning. The students are supposed to do the necessary researching, brainstorming, and guessing to discover the meaning and choose the correct option (e.g., Unit 2, pages 26 \& 33; Unit 9, pages $115 \& 125$ ). 
Count Me 1 The activities in the units do not seem to allow students to make any discoveries In or investigations. For example, on page 30, the students are asked to write an opinion essay but there is no opportunity to discuss the language they use with the teacher or their pairs after completing the task. The only observable part that can help students to make discoveries about English in use is the stress pattern activity on page 30. The students are expected to read aloud the given words and guess the stress patterns. Then they need to listen to the actual pronunciations and check if they get them right.

Table 8. Providing opportunities to use the target language for communication

\begin{tabular}{|c|c|c|}
\hline Course & Score & Comments \\
\hline Teenwise & 2 & $\begin{array}{l}\text { There are a couple of activities in the units which seem to be able to provide } \\
\text { communicative opportunities to use the target language. For example, on page } \\
\text { 112, students are asked to plan an imaginary birthday party, and talk about their } \\
\text { preparations. Similarly, Activity } 6 \text { on page } 27 \text { asks the students to work in groups, } \\
\text { bring a picture of their rooms, and compare. However, there are also some } \\
\text { activities (e.g., Activity } 6 \text { on page 111) which have no specific outcome and even } \\
\text { constrain the students' speaking process. They ask students to write their own } \\
\text { dialogue by changing the colored parts of a conversation given in the previous } \\
\text { activity, and then role-play them. The role-play is strictly limited to the already } \\
\text { provided dialogue, and students can only change a few words. If the students were } \\
\text { given an opportunity to do some changes to the role-play in any way they would } \\
\text { like to, it could effectively provide ample opportunities for them to use the target } \\
\text { language for communicative purposes. }\end{array}$ \\
\hline
\end{tabular}

English $10 \quad 3 \quad$ The speaking activities and discussion parts of the units provide the students with a plenty of opportunities to communicate in the target language. The activities possess the required potential to trigger spontaneous speaking moments. For example, the speaking activity on page 121 asks students to share their opinions about what they would do if they were a hero or heroine. In a different activity on page 30, the students are supposed to take notes about their future to present in class. Activity A on page 26 also contributes in terms of presenting communicative opportunities by giving the students expressions they can use while making plans. Activity $\mathrm{B}$ on the same page is a role-play activity where they can use the new expressions they would learn in a communicative context. In fact, such kinds of activities seem to be able to pave the way for the students to use the target language for communication.

Sunshine $\quad 2$ Comprehension check questions and activities (e.g., pages 26 \& 114) abound in the English units. Hence, they seem to fail to open up ample opportunity for the students to reply in a communicative way. However, there are a couple activities that seem to able to offer communicative production. For example, Activity 5 on page 25 asks the students to walk around the class and talk to other students to find who fits the correct adjectives and situations. Another similar activity can also be seen on page 116 in Unit 9, in which the students are asked to walk around the classroom and talk to find students who do the activities given in the activity table. Then they are supposed to summarize each statement using adjectives. Such kinds of activities can provide opportunities to exploit the target language for communication.

Count Me 1 The writing and speaking tasks in the units are mainly practice activities in In which learners are told what to say and how to say. For example, in Unit 2, students are asked the question what animals are known for loyalty with a couple of constrained answers to choose from. In fact, little opportunity is provided for the students to communicatively express their own beliefs. Some simulation activities, however, provide some opportunities to use the target language for communication. For example, on page 86 , the students are asked to make a list of whatever they know about web pages and to discuss what they would write about 
in their group. Such kinds of activities can give them a chance to communicate in the target language. However, only 2 out of 10 writing and speaking activities provide communicative opportunities to the learners in the units.

Table 9. Developing cultural awareness

\begin{tabular}{|c|c|c|}
\hline Course & Score & Comments \\
\hline Teenwise & 2 & $\begin{array}{l}\text { In general, the units seem to partially foster cultural awareness of the learners } \\
\text { although there is a plenty of cultural references in the units, and ample } \\
\text { opportunities for students to develop cultural awareness. For example, on page } 31 \text {, } \\
\text { in Unit } 2 \text {, there is an activity in which three people from different countries and } \\
\text { cultures talk about their sleeping habits based on their cultures. There is also a } \\
\text { different activity on page 118, in Unit } 9 \text {, which gives some information about a } \\
\text { festival in India. This activity informs students of other cultures and their } \\
\text { traditions. However, the cultural information could have been effectively used in } \\
\text { the coursebooks to enable the learners to learn 'from' culture, rather than 'about' } \\
\text { culture (Kumaravadivelu, 2003). Hence, despite the wealth of cultural references } \\
\text { in the units, the contents do not seem to be able to culturally involve the learners } \\
\text { in the activities as the coursebook only acts as a transmitter of cultural } \\
\text { information. }\end{array}$ \\
\hline
\end{tabular}

English $10 \quad 1$ On page 34, there is a character from Bosnia, but there is no information about the country or the culture. In the other unit, some information is given about two distinguished Turkish scientists, Canan Dağdeviren and Aziz Sancar. All in all, the cultural references in the coursebook are mostly Turkish characters and cultural facts about Turkey. Even some units are solely dedicated to the characters from Turkish culture (e.g., pages $49 \& 125)$. In fact, the units seem to fail to help the learners develop cultural awareness.

Sunshine $\quad 1$ There are some texts about countries other than Turkey. In addition, there are English illustrations and pieces of information about celebrities who are from other countries. However, the activities do not attempt to develop cultural awareness. There is a text on page 123 which provides some information about Turkey and Hungary, focusing on their cultural and historical ties. However, such kinds of activities do not seem to be able to involve the learners culturally, and hence foster their cultural awareness. In the text on page 117, many countries are mentioned; however, there is no attempt to raise cultural awareness about these countries, and no attempt to connect the students' culture as cultural informants in the classroom.

Count $M e \quad 1 \quad$ There is seemingly no attempt to make the students become aware of any cultural In traits. Nor is there any cultural information about and connection to the students' own culture. The texts are unauthentic and there is no input about culture. There is only one activity on page 27 which points to physical and racial differences; however, it cannot be considered as cultural information or an attempt to raise the cultural awareness of the students.

Table 10. Helping the learners to make use of the English environment outside the classroom

\begin{tabular}{lcl}
\hline Course & Score & \multicolumn{1}{c}{ Comments } \\
\hline Teenwise & 1 & $\begin{array}{l}\text { In the units, there is no attempt to encourage the learners to make use of English } \\
\text { in their actual or virtual environment outside the classroom even though there } \\
\text { are potential activities that could have been effectively used. For example, an } \\
\text { activity on page 114 asks students to write a letter to a friend. However, the letter } \\
\text { template is on the page, and they are supposed to write the letter on the page } \\
\text { rather than writing it on a piece of paper at home and sending it to a real friend, } \\
\text { which could potentially teach them how to have a pen pal. }\end{array}$
\end{tabular}


English $10 \quad 3$ The coursebook has a video blog entry part in each unit. It gives the students an opportunity to make use of English outside the classrooms. The activities also require the students' peers to comment and evaluate their friends' video (e.g., pages $30 \& 122$ ). Hence, learning outside the classroom seems to be quite promoted with technology in this coursebook.

Sunshine $\quad 3$ There are many attempts to get the students do research and do activities outside English the classroom in the coursebook. Each unit has a few e-portfolio and video blog activities. In addition, some activities ask students to do research outside the classroom and then present in the class. For example, Activity 17 on page 120 asks students to browse on the internet, find detailed information about their favorite celebrity, write a paragraph giving detailed information about him/her, and finally share with their friends.

Count $M e \quad 1$

In

In the units, no attempt is made to encourage the learners to make use of English in their actual or virtual environments outside the classroom. Task E on page 30, for example, suggests learners to write an opinion essay but there is no further instruction on what and how to do it.

Table 11. Catering for the needs of all the learners

\begin{tabular}{|c|c|c|}
\hline Course & Score & Comments \\
\hline Teenwise & 1 & $\begin{array}{l}\text { In Unit } 9 \text {, the assumption seems to be that all students are physically capable and } \\
\text { kinesthetic learners as there are many role-play activities (e.g., pages } 111,117, \& \\
\text { 120). Students who have low self-esteem and stage fright might have a hard time } \\
\text { with such kinds of one-size-fits-all activities. Hence, the coursebook seems to fail } \\
\text { to take into account the learning styles of the learners, and the ones with physical } \\
\text { disabilities. }\end{array}$ \\
\hline English 10 & 2 & $\begin{array}{l}\text { In the units, there is an assumption that all the learners are Turkish and know } \\
\text { about the Turkish culture (e.g., pages } 117,122,123 \& 125) \text {. In addition, contents } \\
\text { presume that all students have easy access to the internet and technological } \\
\text { devices. For example, vlog activities in each unit ask students to record video } \\
\text { blogs about various topics and upload them to their own individual blogs. } \\
\text { However, the units consist of activity parts based on the four language skills and } \\
\text { multiple intelligences. For example, each unit has a song section appropriate for } \\
\text { auditory learners on page } 127 \text {, discussion time for interpersonal learners on page } \\
\text { 126, and acting out activities appropriate for kinesthetic learners. }\end{array}$ \\
\hline $\begin{array}{l}\text { Sunshine } \\
\text { English }\end{array}$ & 2 & $\begin{array}{l}\text { Similar to English } 10 \text { coursebook, in this coursebook the contents presume that all } \\
\text { students are Turkish and know about the Turkish culture. The all students are } \\
\text { also presumed to have easy access to the internet connection and technological } \\
\text { gadgets. For example, e-portfolio and vlog activities in each unit ask students to } \\
\text { complete the activities online on their online portfolios (pages } 27 \& 119 \text { ). However, } \\
\text { similar to English 10, this coursebook also has diverse activities with different } \\
\text { learning styles such as listening tracks on page } 114 \text { or visuals on pages } 120-121 \text {, } \\
\text { and online activities that can be useful to the students who are interested in } \\
\text { technology. }\end{array}$ \\
\hline $\begin{array}{l}\text { Count Me } \\
\text { In }\end{array}$ & 1 & $\begin{array}{l}\text { In Unit } 9 \text {, there is similar assumption that all students are technophiles (pages } 86 \\
\& 90 \text { ). Unit } 2 \text { similarly requires the students to have some friends in and outside } \\
\text { the classroom to complete the activities (pages } 22,23,24 \& 28 \text { ). The contents seem } \\
\text { to ignore the fact that some might be introverts or asocial with not many friends. } \\
\text { The texts are generally conversations between two people who seem to be } \\
\text { Europeans. There is no task requiring kinesthetic activity, and students can } \\
\text { answer the questions while seated. In this regard, this coursebook is also void of } \\
\text { activities that integrate the learning styles and preferences of the learners. }\end{array}$ \\
\hline
\end{tabular}

Table 12. Providing the flexibility for effective localization 


\begin{tabular}{|c|c|c|}
\hline Course & Score & Comments \\
\hline Teenwise & 1 & $\begin{array}{l}\text { None of the activities in the units asks questions that allow localization except the } \\
\text { Activity } 7.2 \text { on page } 120 \text {, which introduce a festival and consequently asks } \\
\text { whether there is a similar festival in the student's country, and how it is } \\
\text { celebrated. In this regard, the coursebook does not seem to be able to provide the } \\
\text { flexibility required for effective localization. }\end{array}$ \\
\hline English 10 & 1 & $\begin{array}{l}\text { There are few activities that invite the learners to make productive localization. } \\
\text { Only } 2 \text { out of } 78 \text { activities in Units } 2 \text { and } 9 \text { effectively allow students to make } \\
\text { localization. These activities are on page } 24 \text {, Activity B "Which celebration types } \\
\text { are popular in your country?", and on page } 34 \text {, Activity B "Imagine you have the } \\
\text { chance to represent your country on the international platform. Would you like to } \\
\text { choose any of the following areas? If yes, which one(s)? Why?" }\end{array}$ \\
\hline $\begin{array}{l}\text { Sunshine } \\
\text { English }\end{array}$ & 1 & $\begin{array}{l}\text { The activities in this coursebook are extensively localized. Almost all the activities } \\
\text { and texts are connected to Turkey, and almost all the characters are Turkish. The } \\
\text { texts are mostly about Turkey and Turkish history and culture. There is no } \\
\text { question or activity that requires students to localize their answers. Such kinds of } \\
\text { source culture materials that only draw on the learners own culture as content } \\
\text { rather than target cultural perspectives cannot help the students who seek to } \\
\text { improve their intercultural competence. Given the fact that students are already } \\
\text { familiar with local topics, the coursebook may fail to motivate students to trigger } \\
\text { the conversations and discussions. In sum, the contents firstly need to be based on } \\
\text { international target culture to be able to be localized consequently. Hence, this } \\
\text { coursebook does not seem to be able to fulfill the requirements of the criterion. }\end{array}$ \\
\hline $\begin{array}{l}\text { Count Me } \\
\text { In }\end{array}$ & 1 & $\begin{array}{l}\text { There is no activity that can potentially invite the learners to relate topics to their } \\
\text { own culture, nor do the contents provide the flexibility needed for effective } \\
\text { localization. }\end{array}$ \\
\hline
\end{tabular}

Table 13. Helping the learners to continue to learn English after the course

\begin{tabular}{|c|c|c|}
\hline Course & Score & Comments \\
\hline Teenwise & 1 & $\begin{array}{l}\text { No attempt is made to develop the skills, provide resources, or maintain the } \\
\text { students' enthusiasm that would encourage them to keep learning English after } \\
\text { the course. Nor is there any encouragement for self-studying after the course. }\end{array}$ \\
\hline English 10 & 2 & $\begin{array}{l}\text { In each unit there is an e-portfolio entry part, and some attempts are made to } \\
\text { develop skills and resources that would allow students to learn English after the } \\
\text { course. In these activities, the students are expected to prepare presentations } \\
\text { about certain topics with the help of details and visuals to present them to their } \\
\text { classmates in the following weeks. However, this is the only activity that can be } \\
\text { potentially considered an attempt to help the learners continue learning English } \\
\text { after the course. }\end{array}$ \\
\hline $\begin{array}{l}\text { Sunshine } \\
\text { English }\end{array}$ & 2 & $\begin{array}{l}\text { There are some activities in the units that can develop the students' skills, } \\
\text { resources, and enthusiasms to continue learning after the course. For example, } \\
\text { the e-portfolio activity on pages } 27 \text { and } 119 \text { ask the students to do research and } \\
\text { update their blogs. The students can use their blogs after the course ends. E- } \\
\text { portfolio activities in the coursebook can potentially create an opportunity for the } \\
\text { students to practice English even after the course ends. }\end{array}$ \\
\hline $\begin{array}{l}\text { Count Me } \\
\text { In }\end{array}$ & 1 & $\begin{array}{l}\text { No attempt is made to develop the skills, resources or enthusiasms that would } \\
\text { help the learners to continue to learn English after their course, and there is } \\
\text { literally no encouragement for learner autonomy during the course to pave the } \\
\text { way for self-studying after the course. }\end{array}$ \\
\hline
\end{tabular}


Table 14. Helping learners to use ELF

\begin{tabular}{|c|c|c|}
\hline Course & Score & Comments \\
\hline Teenwise & 2 & $\begin{array}{l}\text { British English is the dominant variety of English in the coursebook. Most of the } \\
\text { students in dialogues have typical native English speaker names (e.g., Mike, } \\
\text { Kelly, Greg, Daisy, and Gina) and some words (e.g., colour and neighbourhood) are } \\
\text { written in British English. However, in Unit } 2 \text {; many countries are mentioned, } \\
\text { and there are some photos of students that represent different countries and } \\
\text { cultures. For example, on page } 31 \text {, there are students from Japan, Morocco, and } \\
\text { Sweden, using ELF and describing their rooms that are typical of their culture. }\end{array}$ \\
\hline English 10 & 1 & $\begin{array}{l}\text { Similar to Teenwise, the dominant variety in this coursebook is British English. In } \\
\text { each unit, there is a reference to only one literary work written by a non-native } \\
\text { author; however, it is simply insufficient to promote usage of ELF. }\end{array}$ \\
\hline $\begin{array}{l}\text { Sunshine } \\
\text { English }\end{array}$ & 1 & $\begin{array}{l}\text { There is no dominant variety of English in the coursebook. In addition, none of the } \\
\text { literature works belong to someone from a non-English speaking country. Hence, } \\
\text { this coursebook does not seem to help learners to use ELF. Nor does it make any } \\
\text { attempt to familiarize the students with different English varieties apart from the } \\
\text { native-speaker varieties of English. }\end{array}$ \\
\hline $\begin{array}{l}\text { Count Me } \\
\text { In }\end{array}$ & 1 & $\begin{array}{l}\text { Japan is the only non-native speaker county that is mentioned in the coursebook. } \\
\text { Additionally, Mina is the only Turkish name that can be found in the coursebook. } \\
\text { It seems that there is no noticeable accent use, nor is there a dominant variety of } \\
\text { English in the coursebook. In sum, students are not exposed to use ELF in the } \\
\text { coursebook. }\end{array}$ \\
\hline
\end{tabular}

Table 15. Helping learners to become effective communicators in English

\begin{tabular}{|c|c|c|}
\hline Course & Score & Comments \\
\hline Teenwise & 3 & $\begin{array}{l}\text { The coursebook abound the communicative activities (e.g., Activity } 7 \text { on page } 111 \text {; } \\
\text { Activity } 7 \text { on page } 114 \text {; Activity } 7 \text { on page } 117 \text {; Activity } 7 \text { on page } 27 \text {; and Activity } \\
2 \text { on page 28) which aim at helping learners use English to achieve effective } \\
\text { outcomes by asking them questions that promote communication. }\end{array}$ \\
\hline English 10 & 2 & $\begin{array}{l}\text { The focus is on correct comprehension of what they write, listen, and read (e.g., } \\
\text { Activity A on page 26) rather than helping learners to use English in effective } \\
\text { communications. However, there are also discussion-based activities (e.g., Activity } \\
\text { A on page } 34 \text { \& Activity A and B on page 126) which offer students discussion } \\
\text { topics in each unit which can practice their communicative competence. }\end{array}$ \\
\hline $\begin{array}{l}\text { Sunshine } \\
\text { English }\end{array}$ & 2 & $\begin{array}{l}\text { The activities mostly focus on accuracy, but the coursebook possesses discussion } \\
\text { time parts that focus on getting the learners to achieve communicative } \\
\text { effectiveness (e.g., Unit } 9 \text {, page 110). In addition, there is a role-play activity on } \\
\text { page } 26 \text { in Unit } 2 \text { which also promotes the effective communication by making the } \\
\text { students imagine, write, do a role-play, and make a video. }\end{array}$ \\
\hline $\begin{array}{l}\text { Count } M e \\
\text { In }\end{array}$ & 1 & $\begin{array}{l}\text { The focus of the activities in the coursebook is to obtain the correct answers from } \\
\text { the students rather than make them communicate. The learners do not need to } \\
\text { read critically. However, there are a few questions that allow discussion even } \\
\text { though they are limited. For example, Task } 7 \text { a on page } 28 \text { encourages learners to } \\
\text { discuss the topics with their friends but by only using the already given set of } \\
\text { words. }\end{array}$ \\
\hline
\end{tabular}

Table 16. Achieving its stated objectives

\begin{tabular}{lll}
\hline Course & Score & Comments \\
\hline
\end{tabular}




$\begin{array}{lll}\text { English } 10 & 1 & \text { No objectives are stated in the coursebook. } \\ \text { Sunshine English } & 1 & \text { No objectives are stated in the coursebook. } \\ \text { Count Me In } & 1 & \text { No objectives are stated in the coursebook. }\end{array}$

\section{Discussion}

Implementing Tomlinson and Masuhara's (2013) set of 15 universal coursebook evaluation criteria, this study sought to evaluate a series of public high school coursebooks used in English courses of the curriculum prepared by the Turkish Ministry of National Education. The coursebooks were being used at the 9th, 10th, 11th and 12th grades of Turkish public high schools in Turkey. The overall averages of the coursebooks are indicated in Table 17. As evident, the average scores of the four coursebooks are moderate. The 11th grade English coursebook was indicated to have the highest average scores $(M=2)$, while the 12th grade English coursebook exhibited the lowest average score $(\mathrm{M}=1.1)$.

Table 17. The average scores of the coursebooks

\begin{tabular}{ll}
\hline Coursebooks & Average Scores \\
\hline $\begin{array}{l}\text { High School English } 9^{\text {th }} \\
\text { Grade Coursebook }\end{array}$ & $\begin{array}{l}\text { Overall: } 1.8 \\
\text { Likely to be partially effective in facilitating long-term acquisition }\end{array}$ \\
$\begin{array}{l}\text { High School English 10 } \\
\text { Grade Coursebook }\end{array}$ & $\begin{array}{l}\text { Overall: } 1.7 \\
\text { Likely to be partially effective in facilitating long-term acquisition }\end{array}$ \\
$\begin{array}{l}\text { High School English 11th } \\
\text { Grade Coursebook }\end{array}$ & Overall: 2 \\
High School English $12^{\text {th }}$ & Overall: 1.1 \\
Grade Coursebook & Unlikely to be effective in facilitating long-term acquisition \\
\hline
\end{tabular}

The evaluation of the $9^{\text {th }}$ grade coursebook, i.e., Teenwise, indicated that while the coursebook is far away from being authentic, the activities in general strive to draw the students' attention and engage them cognitively. The coursebook also seems to provide appropriate challenges for the students and possesses the potential to improve student motivation. Even though the coursebook can be considered successful in terms of personalization and cultural awareness, it seems to fail when it comes to localization. In addition, the coursebook fails in terms of providing exposure to the students, nor does it encourage learning outside the classroom. However, the coursebook is quite successful in terms of communication opportunities. The activities do not require the answers to be strictly based on the given topics, and this effectively gives the students the autonomy to use English for their own communicative purposes. In a nutshell, the coursebook has the average point of 1.8 on 15 criteria, and it does not seem to ensure a significant language development and thereby long-term language acquisition. 
The criteria-based evaluation of the 10th grade coursebook, i.e., English 10, revealed that the activities in the coursebook predominantly focus on the comprehension checks rather than the active involvement of the students. Furthermore, the coursebook seems to be inadequate in terms of effectiveness and cognitive engagement of the 10 graders. As for challenges, the coursebook can be considered successful since the activities provide challenges that are appropriate for the proficiency level of the students. However, the results indicated that the coursebook is insufficient in terms of providing personalization, localization, and cultural awareness. Additionally, the coursebook gives the students a chance to develop their communication skills in the classroom. All in all, the average point of the coursebook is 1.7 which implies that the coursebook is likely to be partially effective in facilitating long-term acquisition if appropriately implemented and supplemented in the classroom.

The evaluation results indicate that the 11 th grade coursebook, i.e., Sunshine English, is void of providing appropriate exposure to English in use and thereby showing the students how English is usually used. Apart from the use of English idioms, there is almost no exposure to natural English throughout the coursebook and it lacks authenticity. In fact, the coursebook can be considered cognitively engaging in terms of activities. The questions that come after the main activities, however, do not count since they are mostly comprehension checks. Additionally, the coursebook can be considered quite effective in terms of providing students with opportunities to make localization, cultural development and personalization in their learning, and internalization processes. The coursebook allows students to make communicative productions to some extent and promotes out of classroom English learning which can help students make practice a lot. All in all, the coursebook has the average point of 2 based on the 15 criteria evaluation, which means that the coursebook is likely to be partially effective in facilitating long-term acquisition.

The evaluation of the 12 th grade coursebook, i.e., Count Me In, revealed that the exposure to English in use is insufficient in the coursebook, and it seems to fail in terms of helping students to make discoveries about how English is typically used. Indeed, the students do not get to discuss what they discover, nor do they sufficiently get exposed to English in context. Additionally, the coursebook does not seem to fulfill the requirements of the communication related criteria. The activities in the coursebook seem to only target to extract the right answers rather than get the learners to communicate effectively. The coursebook also fails to get students to use English outside of the classroom and to engage the learners cognitively. There is little opportunity for students to think creatively or imaginatively in the coursebook. Localization, personalization and developing cultural awareness are also insufficient in the coursebook. Specifically, there are no activities that invite the learners to relate the topics to their own countries or personal lives. Nor are there any opportunities to compare their cultures with other cultures as there are almost no cultural references. All in all, the coursebook has the average point of 1.1 which means that the book is unlikely to be effective in facilitating long-term acquisition. 
In fact, all the coursebooks except the $12^{\text {th }}$ grade coursebook seem to be partially effective in facilitating long-term acquisition of English. Indeed, Count $\mathrm{Me} \mathrm{In}$ coursebook with the lowest average point out of four coursebooks is unlikely to be effective in facilitating long-term acquisition. Specifically, the texts in the coursebook are not interesting enough. Indeed, the students need topics that can make them feel excited in their last year of high school. The coursebooks would have a higher potential for successful outcome, provided that the teacher does not solely rely on the contents of the coursebooks. The moderate effectiveness of the three coursebooks (i.e., Teenwise, English 10, and Sunshine) for the long-term language acquisition seems to simply imply that they need to be supplemented, and the teachers need to adopt and develop the materials so as to effectively use the coursebooks in the classroom.

\subsection{The features requiring improvement in the coursebooks}

In the evaluation, we identified several deficient traits in the Turkish public high school English coursebooks that are likely to impede long-term language acquisition. For example, they fail to encourage learners to use English outside the class, they lack discovery enhancing activities, and they are void of extensive exposure to English. It seems that the prime emphasis of the coursebooks is on the linguistic output and the accuracy rather than the meaningful communication and outcome. Most of the activities in all the coursebooks are practice activities that do not advocate learner autonomy and productivity. Indeed, the repetitive practice activities that only assess accuracy do not seem to lead to long-term acquisition of English.

In addition, although there is a varying number of topics that can be potentially used for personalization and localization, the coursebooks predominantly rely on a third person rather than the learners themselves. In a nutshell, personalization in the coursebooks is simply insufficient, and the coursebooks seem to fail to use the knowledge and the worldviews that learners bring with them to the class. Students need to be treated as cultural informants in the classroom, and the cultural knowledge they possess need to be effectively used in the classroom. Encouraging them to share their own individual perspectives with the teacher and the other students whose lives, and hence perspectives, differ from theirs can potentially lead to long-term acquisition (Kumaravadivelu, 2003). In fact, the activities in the Turkish public high school English coursebooks do not seem to privilege the individual knowledge the students bring with them to the class. Additionally, the activities in the coursebooks seem to fail to make the learners think analytically, creatively, or critically. Besides, the coursebooks need to integrate more kinesthetic activities that would get the students to be more active in the class. The mechanical activities with no space for kinesthetically keeping the students active in the class do not seem to cater for the needs of the learners. The focus of the activities is on language items within the classroom environments, and language acquisition is only constrained to the class environment. Specifically, the activities and the tasks exhibit constrained attempts to promote the usage of English outside the course. Finally, none of the coursebooks have objectives stated anywhere. It would be effective for both students 
and teacher to observe what they do and what they will be capable of doing once the course ends.

Indeed, the unsatisfactorily low average scores of the coursebooks underline the deficiency of the materials in public high schools in Turkey. The general inadequacy of the coursebooks in Turkish public-school English has also been identified in a number of studies (e.g., Çakıt, 2006; Tılfarlioglu \& Öztürk, 2007; Kayapnar, 2009; Dülger, 2016). In Tilfarlığlu and Öztürk's (2007) examination, for example, the coursebooks were reported to be highly inadequate, which has given rise to language teachers' overreliance on reading and grammar in Turkish public schools as the readings passages and grammatical points abound in the coursebooks. In the same vein, Çakı (2006) and Dülger's (2016) studies revealed both students and teachers' discontent with the English language coursebooks used in Turkish public schools. Indeed, the body of studies on the efficiency of the materials in general and the coursebooks in particular exhibits both Turkish students and teachers' somewhat dissatisfaction with the contents of the materials. Çelik and Kasapoğlu (2014) investigated the school administrators' perceptions on teaching English to young learners and on language teaching in Turkey. The administrators stated their deep concerns about the recent reform's effect on English education in Turkey, and they exhibited that a major action and revision need to be promptly taken regarding the language education in Turkey. The Economy Policy Research Foundation of Turkey and the British Council's joint investigation run by Vale et al. (2013) on the Turkish students' linguistic deficiency also revealed five main reasons behind the English deficit in Turkish public schools, one of which is the inadequacy of public schools English coursebooks. Indeed, the report asserts that the coursebooks in use and the curricula are not appropriate to the individual students' level of proficiency and the needs in language education.

\subsection{Positive features of the coursebooks}

On the other hand, the four coursebooks can be considered quite successful in respect of providing students with (1) communicative opportunities, (2) use of idioms, (3) integrated technology, (4) self-evaluation opportunities, and (5) illustrations in use. Except the $12^{\text {th }}$ grade coursebook, the other three coursebooks have high scoring in communication criterion. Even though they focus on accurate production rather than fluency, the integration of communicative activities can potentially improve the students' communicative competence. Added to that, all the coursebooks we evaluated include special parts that have idiomatic expressions and quotations, some of which ask the students to guess the meaning and/or find the meaning through investigation. They can thus offer an ample opportunity to examine English in daily context. It is worth noting that idioms possess a big importance in language acquisition since they require a deeper familiarity with the language to comprehend what someone intends to express in conversations, and thereby the inclusion of idiomatic expressions can offer students a great chance to widen their linguistic repertoire. 
In addition, technological literacy is undoubtedly a must-have skill in the era of education, and the development of educational technology and materials, over the last decades, has facilitated the process of language learning so as to fulfill the requirements of current generation that is being considered digital natives. The coursebooks include sections that ask the students to create and develop e-portfolios, vlogs, or blogs which aim to have the students practice and develop their technological skills in and outside the classroom. Additionally, at the end of each unit, there is a self-evaluation rubric for the students to check and monitor their own learning. This practically allows students to master their meta-cognitive skills and provides them with insights about their own learning and progress. The illustrations in use are the positive feature of the coursebooks as well. The coursebooks include a various number of pictures that can potentially grab the students' attention and peak their interests. They can also help them with visualizing the topics. Indeed, although Tomlinson and Mashuara (2013) do not focus on visuals in their criteria, they can be of prime importance in terms of involving the students in meaningful learning as pictures require paying attention, especially if they are used within activities. Even though the evaluated coursebooks do not target young learners, they contain many visuals and fun layouts.

\section{Conclusion}

Having a major supporting role in language classes, coursebooks are the commonly used materials in language education. Provided the fact that Turkey has been consistently ranked very low on globally recognized proficiency benchmarks over the last decades, immediate and effective measures need to be taken to critically revise the Turkish public school English coursebooks. These measures will pave the way for more efficient instruction of English in Turkish schools. The findings call for the urgent actions that need to be taken by the Turkish Ministry of National Education to improve the contents of the English coursebooks that are currently being used in Turkish public schools. This would thereby help to strengthen the English proficiency of the Turkish students studying at public schools.

As aforementioned, despite the claims of the coursebook evaluations in terms of being standardized and accurate, the nature of any evaluation unavoidably tends to be subjective. Hence, even though the evaluation interpretations of the coursebooks in the current study were in parallel with the universal coursebook evaluation criteria, they would be likely to differ if conducted by a different group of evaluators. It is also worth underlining that in the current study, we only conducted the pre-use evaluation of the Turkish public school coursebooks with no insights from the students or the teachers. The examinations with the focus on whilst-use evaluation, and post-use evaluation of the coursebooks would surely shed more lights on their potential effectiveness and thereby short-term and long-term efficiency of the coursebooks in language education. The Turkish public high school students and teachers' perceptions as a determining factor in deciding on the quality of the coursebook contents also appear to be fruitful avenues for future research. 


\section{The Research and Publication Ethics Statement}

The data were collected through the evaluators' interpretations. No ethical considerations were violated in this study.

\section{The Conflict of Interest Statement}

In line with the statement of Committee on Publication Ethics (COPE), we hereby declare that we had no conflicting interests regarding any parties of this study.

\section{References}

Abdelwahab, M. M. (2013). Developing an English language textbook evaluative checklist. IOSR Journal of Research \& Method in Education, 1(3), 55-70. http://doi.org/10.9790/7388-0135570

Akkaya, S. (2019). An evaluation of 2nd graders' English course book "English 2" from teachers' perspective [Unpublished master's thesis]. Institute of Social Sciences, Istanbul: Istanbul Sabahattin Zaim University.

Allwright, D. (1981). What do we want teaching materials for? ELT Journal, 1, 5-18. https://doi.org/10.1093/elt/36.1.5

Arıkan, G. (2008). Textbook evaluation in foreign language teaching: Time for English, grade 4: Teachers' and students' views [Unpublished master's thesis]. Institute of Social Sciences, Adana: Cukurova University.

Aytuğ, S. (2007). An EFL textbook evaluation study in Anatolian high schools: New bridge to success for 9th grade new beginners [Unpublished master's thesis]. The Graduate School of Education, Ankara: Bilkent University.

Bahman, M., \& Rahimi, A. (2010). Gender representation in EFL materials: An analysis of English textbooks of Iranian high schools. Procedia Social and Behavioral Sciences, 9, 273277. https://doi.org/10.1016/j.sbspro.2010.12.149

Brown, J. B. (1997). Textbook evaluation form, The Language Teacher, 21(10), 15-21.

Byrd, P. (2001). Textbooks: Evaluation for selection and analysis for implementation. In CelceMurcia, M. (Eds.), Teaching English as a second or foreign language (pp. 415-427). Heinle \& Heinle.

Chambers, F. (1997). Seeking consensus in coursebook evaluation. ELT Journal, 51(1), 30-35. https://doi.org/10.1093/elt/51.1.29

Crewe, J. (2011). How far do 'global' ELT coursebooks realize key principles of Communicative Language Teaching (CLT) and enable effective teaching-learning? [Unpublished master's thesis]. The School of Humanities, Birmingham: University of Birmingham

Cunningsworth, A. (1995). Choosing your coursebook. Oxford: Macmillan Heineman.

Çakıt, I. (2006). Evaluation of the EFL textbook "New Bridge to Success 3" from the perspectives of students and teachers [Unpublished master's thesis]. School of Social Sciences, Ankara: The Middle East Technical University.

Çelik, S., \& Kasapoğlu, H. (2014). Implementing the recent curricular changes to English language instruction in Turkey: Opinions and concerns of elementary school administrators. South African Journal of Education, 34(2), 1-14. https://doi.org/10.15700/201412071144

Davcheva, L., \& Sercu, L. (2005). Culture in foreign language teaching materials. In Sercu et al. (Eds.), Foreign language teachers and intercultural competence (pp. 90-109). Multilingual Matters LTD. https://doi.org/10.21832/9781853598456-008 
Dodgson, D. (2019). 6 reasons for using coursebooks (from a teacher who doesn't usually like them). Retrieved on February 15, 2020 from https://www.modernenglishteacher .com/2019/6-reasons-for-using coursebooks-from-a-teacher-who-doesn-t-usually-like-them

Dubin, F., \& Olshtai, E. (1986). Course design: Developing programmes and materials for language learning. Cambridge: Cambridge University Press.

Dülger, O. (2016). Evaluation of EFL coursebooks taught in Turkey based on teachers' views. Journal of Advances in English Language Teaching, 4(1), 1-11.

Gearing, K. (1999). Helping less experienced teachers of English to evaluate teacher's guides, ELT Journal, 53(2), 122-127. https://doi.org/10.1093/elt/53.2.122

Gray, J. (2002). The global coursebook in English language teaching. In D. Block \& D. Cameron (Eds.), Globalization and language teaching (pp. 151-167). London: Routledge

Gray, J. (2006). A Study of cultural content in the British ELT global coursebook: A cultural studies approach [Unpublished doctorate dissertation]. Institute of Education. London: University of London.

Haycroft, J. (1978). An introduction to English language teaching. The UK: Longman.

Hutchinson, T., \& Torres, E. (1994). The textbook as agent of change. ELT Journal, 48(4), 315327.

Johnson, D. M. (1992). Approaches to research in second language learning. New York: Longman.

Kayapınar, U. (2009). Coursebook evaluation by English teachers. Inonu University Journal of the Faculty of Education, 10(1), 69-78.

Kramsch, C. (1988). The cultural discourse of foreign language textbooks. In A. J. Singerman (Eds.), Toward a new integration of language and culture (pp. 63-88). Middlebury, VT: Northeast Conference on the Teaching of Foreign Languages.

Kumaravadivelu, B. (2003). Beyond methods: Macrostrategies for language teaching. Hartford, CT: Yale University Press.

Littlejohn, A. (1998). The analysis of language teaching materials: Inside the Trojan horse. In B. Tomlinson (Eds.), Materials development in language teaching (pp. 190-216). Cambridge: Cambridge University Press.

Masuhara, H., Hann, N., Yi, Y., \& Tomlinson, B. (2008). Adult EFL courses. ELT Journal, 62(3), 294-312.

McDonough, J., \& Shaw, C. (1993), Materials and methods in ELT: A teacher's guide. London: Blackwell.

McKay, S. L. (2003). Toward an appropriate EIL pedagogy: Re-examining common ELT assumptions. International Journal of Applied Linguistics, 13(1), 1-22. https://doi.org/10.1111/1473-4192.00035

McKay, A., \& Gass, S. A. (2016). Second language research (2nd edition). New York: Routledge.

Mukundan, J., \& Ahour, T. (2010). A review of textbook evaluation checklists across four decades (1970-2008). In B. Tomlinson \& H. Masuhara (Eds.), Research for materials development in language learning: Evidence for best practice (pp. 336-52). London: Continuum.

Öz, Ö. (2019). A post-use evaluation of an EFL coursebook from the perspectives of preparatory school students and instructors: A mixed methods study [Unpublished master's thesis]. The Graduate School of Social Sciences, Ankara: Middle East Technical University.

Özdemir, F. E. (2007). An evaluation of Time for English 4, the 4th grade English coursebook for public schools [Unpublished master's thesis]. School of Social Sciences, Ankara: Middle East Technical University. 
Pennycook, A. (1994). The Cultural politics of English as an international language, London: Longman.

Sercu, L. (2005). The future of intercultural competence in foreign language education: Recommendations for professional development, educational policy and research. In Sercu et al. (Eds.), Foreign language teachers and intercultural competence (pp. 160-185). Clevedon: Multilingual Matters.

Sheldon, L. E. (1988). Evaluating ELT textbooks and materials. ELT Journal, 42(4), 237-246. https://doi.org/10.1093/elt/42.4.237

Skierso, A. (1991), Textbook selection and evaluation. In M. Celce-Murcia and L. McIntosh (Eds.), Teaching English as a second or foreign language (pp. 432-53). Boston: Heinle and Heinle.

Solhi, M., Sak Masrı, M., Şahin, Ş., \& Yılmaz, H. S. (2020). Evaluation of the English language coursebooks used at the Turkish public elementary schools. Journal of Language and Linguistic Studies, 16(3), 1282-1308.

Tılfarlıŏlu, F. Y. \& Öztürk, A. R. (2007). An Analysis of ELT teachers' perceptions of some problems concerning the implementation of English language teaching curricula in elementary schools. Journal of Language and Linguistic Studies, 3(1), 202-217.

Tomlinson, B. (1999). Developing criteria for materials evaluation, IATEFL Issues, 147, 10-13.

Tomlinson, B., Dat, B., Masuhara, H., \& Rubdy, R. (2001). ELT courses for adults. ELT Journal, 55(1), 80-101.

Tomlinson, B. (2012). Materials development for language learning and teaching, Language Teaching: Surveys and Studies, 45 (2), 143-79.

Tomlinson, B. (2013a). Introduction: Are materials developing? In B. Tomlinson (Eds.), Developing materials for language teaching (pp. 1-17). Bloomsbury Publishing Plc.

Tomlinson, B. (2013b). Materials evaluation. In B. Tomlinson (Eds.), Developing materials for language teaching (pp. 21-48). Bloomsbury Publishing Plc.

Tomlinson, B., \& Masuhara, H. (2013). Adult coursebooks. ELT Journal, 67(2), 233-249. https://doi.org/10.1093/elt/cct007

Tsiplakides, I. (2011). Selecting an English coursebook: theory and practice. Theory and Practice in Language Studies, 1(7), 758-764. https://doi.org/10.4304/tpls.1.7.758-764

Ur, P. (1996). A course in language teaching: Practice and theory. Cambridge: Cambridge University Press.

Vale, D., Özen. E. N., Alpaslan, I. B., Çağll, A., Özdoğan, I., Sancak, M., Dizman, A. O., \& Sökmen, A. (2013). Turkey national needs assessment of state school English language teaching. Ankara: British Council.

\section{Copyrights}

Copyright for this article is retained by the authors, with first publication rights granted to the Journal.

This is an open-access article distributed under the terms and conditions of the Creative Commons Attribution license (CC BY-NC-ND) (http://creativecommons.org/licenses/by-nc-nd/4.0/). 